\title{
Induction of Mutation in Flower Crops-A Review
}

\author{
K. Kayalvizhi ${ }^{\text {* }}$, A. Ramesh Kumar ${ }^{1}$, A. Sankari ${ }^{2}$ and M. Anand ${ }^{3}$ \\ ${ }^{1}$ Horticulture and Floriculture, Central University of Tamil Nadu, \\ Thiruvarur, Tamil Nadu, India \\ ${ }^{2}$ Department of vegetable science, TNAU, Coimbatore, India \\ ${ }^{3}$ Horticulture, Horticultural Research Station, Yecaud, India \\ *Corresponding author
}

\section{A B S T R A C T}

\section{Keywords}

Mutation,

Gamma ray,

EMS, DES and

Ornamental plants

Article Info

Accepted:

18 May 2020

Available Online:

10 June 2020
Mutation is the sudden heritable change that occurred in an organism. It may be caused by spontaneous or through artificial induction and the resulted mutant shows change in the gene or chromosomes. Induced mutagenesis techniques have successfully produced and commercialized quite a large number of new promising varieties in different crops worldwide, including ornamental plants. Induced mutagenesis has been most successful in ornamental crops. The improvement achieved through mutation breeding in ornamental crops includes compact growth, attractive variegated leaves and novel flower colour and shapes. Ornamental plants with a rich variety of flower colors and shapes are highly prized, and the production of mutant cultivars that differ in these traits is in demand because all other growth habits are identical. Many species of ornamental plants, such as chrysanthemum (Chrysanthemum spp.), rose (Rosa spp.), and carnation (Dianthus caryophyllus), are vegetatively propagated, making it relatively easy to propagate mutants. This review not only provides examples of successful mutation breeding results using physical and chemical mutagens, but it also describes research on mutagenesis and compares results of gamma ray, EMS and DES using ornamental plants.

\section{Introduction}

Mutation is the sudden heritable change that occurred in an organism. It may be caused by spontaneous or through artificial induction and the resulted mutant shows change in the gene or chromosomes (De and Bhattacharjee, 2011). Induced mutagenesis techniques have successfully produced and commercialized quite a large number of new promising varieties in different crops worldwide, including ornamental plants. Both physical and chemical mutagens were used for improving the desired characters of flower and ornamental crops such as amaryllis, asiatic hybrid lily, bougainvillea, chrysanthemum, dahlia, gladiolus, hibiscus, Lantana depressa Naud, marigold, rose, tuberose, gerbera, narcissus etc. Induced mutations in ornamentals comprise traits such 
as altered flower characters (colour, size, morphology, fragrance), leaf characters (form, size, pigmentation), growth habit (compact, climbing, branching) and physiological traits such as changes in photoperiodic response, early flowering, free flowering, keeping quality and tolerance to biotic and abiotic stresses. Mutation breeding holds the key advantage of ability to change one or a few characters of an otherwise outstanding variety without altering the unique part of the genotype. (Datta, 2014).

In any mutation breeding programme, selection of an effective and efficient mutagen agent that induce sudden heritable change is very essential to produce high frequency desirable mutants. Several factors such as properties of mutagens and $\mathrm{pH}$, duration of treatment, temperature etc. play pivotal role to produce a desirable mutant. Mutation is induced by physical and chemical mutagen treatment in both seed and vegetative propagated crops. The mechanism of mutation induction is breaking the nuclear DNA and during the process of DNA repair mechanism, new mutations may occur randomly and are heritable.

It is a simple, efficient, rapid and cheap option for obtaining desired genotypes in crops. Induced mutation is one of the most widely used techniques for creating additional variability in desirable character by physical and chemical mutagens. In physical mutagens, atoms are the principal source material. Unstable atoms of same element having different weights giving energy or particles are called radioisotopes and electromagnetic waves associated with nuclear decay are called as radiation and the treatment of an organism or plant with radiation is known as irradiation. It is classified into two groups ionizing and non ionizing radiations. Alpha rays $(\alpha)$, Beta rays $(\beta)$, X-rays, Gamma ray $(\gamma)$ and Neutrons belongs to the group of ionizing radiation. Non ionizing radiation includes UV rays only. Ionizing radiations normally causes chromosomal rearrangements and deletions, that results in mutation.

Gamma rays are electromagnetic radiations having shorter wavelength than $\mathrm{X}$ rays with more energy and penetrating power. It is produced by a number of isotopes viz., ${ }^{14} \mathrm{C}$, ${ }^{60} \mathrm{Co},{ }^{137} \mathrm{Cs}$ etc. for chronic treatments requiring slow irradiation over long periods (De and Bhattacharjee, 2011). Mutation can also be induced chemically with alkylating agents such as Diethyl sulphate (DES) and Ethyl methane sulphonate (EMS). The alkyl group of chemical mutagens reacts with DNA which may change the nucleotide sequence and cause a point mutation. (Broertijes and Harten, 1988). EMS alkylates are guanine bases and leads to mispairing-alkylated $\mathrm{G}$ pairs with $\mathrm{T}$ instead of $\mathrm{C}$, resulting in primarily $\mathrm{G} / \mathrm{C}$ to $\mathrm{A} / \mathrm{T}$ transitions (Bhat et al., 2007). Kayalvizhi et al., (2018) revealed that, tuberose variety Prajwal bulbs treated with different dose of $0.5,1.0,1.5,2.0$ and $2.5 \mathrm{kR}$ gamma rays, induced higher proportion of chlorophyll mutants (xantha', 'chlorina' and 'striata'), broad leaved, non-flowering and floral mutants.

\section{Induced mutagenesis in crop improvement}

Induced mutation is one of the tools used to create wide variability. Since spontaneous mutations occur at a very low frequency and often do not include the full range of variability, mutations are induced in high frequencies by physical or chemical mutagens (Konzak et al., 1961). Zhao (2002) clearly explained that mutation induction techniques can greatly increase the gene mutation frequency which helps to develop new variety and also to meet the breeding targets in a relatively shorter period. Several pioneer workers viz., Muller (1927) and Stadler 
(1928), Swaminathan (1969) and Datta (2014) demonstrated the potential significance of inducing useful mutation. Physical mutagens commonly used are X-rays, gamma rays, fast moving neutrons, thermal neutrons, radio isotopes and ultraviolet rays. The relative frequency of mutations and chromosomal aberrations can be identified by using different mutagens viz., gamma rays, X-rays, neutrons, etc. The choice of mutagen to be made mostly depends upon the breeding material to be used and the objectives of mutation studies. Gamma irradiation has certain advantages over the chemical mutagens viz., no residual effect; uniformity in penetration; less time consuming and large number of samples can be treated in less time.

It provided on high number of useful mutants and is still showing an elevated potential for improving vegetatively propagated plants. Induction of mutation is an important pathway for the production of new genotypes in asexually propagated species and to enhance natural genetic resources (Jyothi and Singh 2016). Ahloowalia and Maluzynski (2001) reported the use of ionizing radiations like $\mathrm{X}$ - rays, gamma rays, neutrons and chemical mutagens for inducing variation in arabidopsis, petunia and antirrhinum.

Zhao (2002) stated that gamma rays was the most commonly used mutagen to induce mutations in fruit trees, ornamental plants, medicinal and aromatic plants, in the past decades of radiation breeding practice in China. Similarly, Wang et al., (2006) also opined that gamma rays were effective in creating mutants and have been successfully used in generation of new crop varieties. Bulbs of tuberose variety Prajwal were subjected to treatments at different doses of gamma ray $(0.5,1.0,1.5,2.0,2.5$ and $3.0 \mathrm{kR}$. Leaf abnormalities (leaf texture and chlorophyll variation) were noticed in $1 \mathrm{kR}$ and $1.5 \mathrm{kR}$ treated bulbs. Gamma rays $0.5 \mathrm{kR}$ resulted in economic traits namely, number of spikes per plant (3 nos.) and number of florets per spike (55 nos.) as reported by Kayalvizhi et al., (2016a).

\section{Induction of mutants by using physical mutagens}

The suitable radiation dose for induction of somatic mutations in chrysanthemum has been done by many workers. The dose of gamma rays to be used obviously depends upon the dose of mutagens, plant part and the stage of development. The dose is varied based on the crop, the method of propagation, the number can be handled and the selection method (Broertjes and Van Harten, 1988).

The wide range of sensitivity among different plant species to X-ray or gamma irradiation is well documented (Sparrow et al., 1963). Differences in radio sensitivity among the species are at least 100 fold and over 50 fold was reported within a species irradiated at different stages (Sparrow et al., 1968).

Radiation injury expresses itself after a few weeks or in some cases years as abnormal shape or appearance, reduced growth or yield, loss of reproductive capacity, sometimes wilting and finally death of plants at the higher rate of exposure. The radio sensitivity of plant species was mainly dependant on the nuclear volume (more sensitivity if the DNA content was greater) and ploidy level (less sensitivity if ploidy level was higher). The survival end points which have been found to be most useful in describing radiation effects on plants were $\mathrm{LD}_{10}, \mathrm{LD}_{50}, \mathrm{LD}_{90}$ and $\mathrm{LD}_{100}$; the exposures required to reduce the plant survival by $10,50,90$ and 100 per cent respectively.

Datta (2014) had given the LD50 value of gamma rays to various flower crops and is presented in table 1 . 
El-Kholy and Hassan (1983) reported reduced germination in Sterlitzia regina by treating the seeds at 500 or 1000 rads of gamma rays either dry or soaked in water for 72 hours. Irradiation reduced average germination from 18 per cent in the control to 9.5 to 14.8 per cent in the treated seeds. Irradiation reduced the number of days for emergence also from 48 in the control to $36-47.5$ with dry seeds with 500 rads. Talukdar et al., (1997) treated chrysanthemum cultivars viz., Snow Ball, Temptation, Raju, Eva Turner and Grape Bowl with $0.5,1.5$ and $2.5 \mathrm{kR}$ gamma rays. A marked reduction in agronomic characters was observed. Moderate to higher doses of gamma rays (1.5 to $2.5 \mathrm{kR}$ ) appeared to be useful in creating stable mutants. Balakrishnan (1997) reported that the $\mathrm{LD}_{50}$ for chrysanthemum cvs. CO 1 and CO 2 were 1.0 and $1.5 \mathrm{kR}$ respectively. Mandal et al., (2000) reported the existence of a negative correlation between the dosage level and the survival rates in two chrysanthemum cultivars Poornima and Colchi Bahar.

Banerji and Datta (2002) treated rooted cuttings of Chrysanthemum morifolium with 100, 150, 200 and $250 \mathrm{~Gy}$ of ${ }^{60} \mathrm{Co}$ gamma rays. Reduction in survival, plant height, no. of branches, leaves, flowers and size were noticed along with increase in foliage and floral abnormalities and chromosomal aberration and delay in flowering at different doses. Srivastava and Mishra (2005) irradiated Hibiscus rosa-sinensis cuttings with gamma rays at various doses to induce mutation and observed that 10 Gy dose resulted in a mutant producing significantly smaller sized flowers due to reduced petal length $(3.3 \mathrm{~cm}$ against $5.2 \mathrm{~cm}$ in the control). Puripunyavanich and Boonsirichai (2008) reported that the bulblets of 'Jongkolnee' water-lily irradiated with gamma rays at 0,50 , 100, 150 and 200 grays (20 bulblets/treatment) yielded two mutant lines. One with the white petals but the flower had the irregular shape (150 Gy). The other had purple flowers with normal flower morphology (100 Gy). In Bougainvillea, promising and beautiful variegated mutants were induced by gamma radiation. Stem cuttings of multi-bracted cultivars viz., Cherry Blossom, Banas Beautya, Mahara, Roseville's Delight were treated with 0, 5, 10 and 15 Gy. Chlorophyll variegation in leaves were detected in all four cultivars while somatic mutation in bract colour were detected in chimera forms in the three varieties namely, Cherry Blossom, Banas Beautya and Roseville's Delight. The mutants were isolated in pure form by chimera management and released as varieties namely 'Arjuna', 'Pallavi', 'Mahara Variegata', 'Los Banas Beautya Variegata', 'Los Banas Beautya Variegata Jayanthi' (Banerji, 2008).

In Taiwan, 37 induced mutant varieties were produced in canna by treating rhizomes and young shoots of eleven cultivars with acute (15-30 Gy) and chronic (65-110 Gy) gamma irradiation (Jompuk et al., 2008). Patil and Patil, (2009) suggested to use gamma rays at lower concentrations (Rose- 5 to $7.5 \mathrm{kR}$, Chrysanthemum- 1.5 to $2 \mathrm{kR}$, Gladiolus- 1 to $5 \mathrm{kR}$, Tuberose- 0.5 to $1 \mathrm{kR}$, Orchid and Carnation- 0.5 to $1.0 \mathrm{kR}$ under in vitro) to obtain useful mutants. Dwivedi and Banerji (2009) irradiated the rooted stem cuttings of Dahila cv. 'Pinki' to gamma radiation at 0 , 250, 500, 1000 and 1500 rads. LD $_{50}$ on survival basis was determined in between 1000 and 1500 rads. Tiwari et al., (2010) studied the effects of gamma rays in the corms of gladiolus. Increased survival percentage was reported in lower dose treated corms $(5 \mathrm{kR})$. Higher the concentration viz., 10 and $15 \mathrm{kR}$ has reduced the survival percentage.

Thinh et al., (2011) irradiated the Phalaenopsis orchid with 0, 20, 40, 60, 100 Gy doses with dose rate of $90 \mathrm{~Gy} / \mathrm{h}$. Three 
years after irradiation treatment, there was a significant influence on growth, mutation frequencies in morphological and physiological traits of Phalaenopsis varieties. Survival rate and growth vigor of treated plants were with higher doses. The useful variation was the highest in $40 \mathrm{~Gy}$ followed by $20 \mathrm{~Gy}$ radiation treatments. $\mathrm{LD}_{50}$ dose for Phalaenopsis orchid variety is $40 \mathrm{~Gy}$. Canna (Canna generalis L. H. Bailey) seed and rhizome were irradiated by gamma ray with five doses and found that the suitable radiation dosage for seed was 40-60 Gy and for rhizome, $10-20$ Gy. The rate of germination, the rate of seedling growth and rate of rhizome survival was decreased and the mutation was raised with the increment of irradiative dosage. When the irradiative dose was over $60 \mathrm{~Gy}$, the mutation rate did not vary and the plant was heavily damaged without ornamental value (Fucui et al., 2011). Kayalvizhi et al., (2017a) reported that, in tuberose prajwal variety bulbs were treated with different doses $0.5,1.0,1.5,2.0$ and 2.5 $\mathrm{kR}$ of gamma rays. In gamma ray 1 and 1.5 $\mathrm{kR}$ treated plants produced chlorophyll mutants such as Striata and also broad leaf mutants observed in 1.5 gamma ray dosage. Gamma ray 1 and $2 \mathrm{kR}$ treated plants produced branched spikes in tuberose. In India, National Botanical Research Institute, Lucknow is the pioneer institution in induction of mutation in flower crops. In bougainvillea, gamma ray was used to induce various mutants and is listed in table 2 (Datta, 2014).

Kainthura and Srivastava (2015) irradiated four tuberose varieties viz., Kalyani Single, Kalyani Double, Suvasini and Prajwal treated with gamma rays $(0.5 \mathrm{kR}$ and $1.5 \mathrm{kR})$ and $\mathrm{X}$ rays $(0.6 \mathrm{kR}$ and $1.2 \mathrm{kR})$. The results indicated that mutagenic treatments at lower doses had significant simulative effect on some parameters i.e., sprouting percentage, days taken to sprouting whereas most of the parameters showed decrease from desired parameters i.e., survival rate, leaf length, number of spikes/plant, number of florets/spike, flowering duration and vase life. Higher doses of all mutagens were detrimental for vegetative and floral characters. Dhivya et al., (2015) reported that crossandra (Crossandra infundibuliformis L.) seeds were treated with different doses of gamma rays $(10,20,30,40$ and $50 \mathrm{kR})$. The $\mathrm{LD}_{50}$ value of gamma rays for seed germination and seedling survival was ranged from 20 to $30 \mathrm{kR}$. Leaf abnormalities were observed at higher doses. Stimulating effect of gamma radiation was observed at 10 and $20 \mathrm{kR}$ whereas almost all the characters showed positive shift including growth and yield attributes.

\section{Chemical mutagens}

Chemical mutagenesis was first reported by Schiemann (1912) in Aspergillus niger. Auerbach (1967) opined that processes such as repair, transcription, translation and competitive cell growth acted as sieves for the expression of mutation and by manipulation of physical, cellular or genetic environment, frequency and spectrum of mutation could be influenced. Mackey (1967) reported that alkylating agents had a reaction pattern more suited than ionizing radiations for breaking down the buffering characteristics of polyploidy germplasm and for creating a maximum genetic diversification and allelic interaction between homologous loci. The chemical mutagens were more dependant on genetic constitution of the plant than the ionizing radiations. Chemical mutagens such as Ethylamine, Ethyl Methane Sulphonate (EMS), Methyl ethane sulphonate (MES), NNitrose Methyl Urea (NMU), Colchicine and Sodium Azide have been normally used (Wen and Qu, 1996). Datta (1990) reviewed that mutagenic chemicals viz., Ethyl Methane Sulphonate, Ethyl Methane Sulphonate, 
Diethyl Sulphate, Ethylamine and N-NitrosoN-Methyl urethane had been successfully used for evolving new mutant cultivars.

\section{Effect of chemical mutagenesis in flower crops}

Singh (1976) noticed a partially pollen sterile plant in petunia by treating the hybrid with 0.2 per cent EMS solution. Hentrich and Glawe (1982) found numerous mutagenic effects on shoots of carnation arising from treated axils with EMS at 1.0 or $2.5 \%$ concentration. Fifteen new variants with altered flower colour and size were selected from the treated population. Schiva et al., (1984) observed that ethyl methyl sulphonate (EMS) was more effective than sodium azide in inducing single gene mutations in gerbera. The seeds were in the mutagen solutions $(6,12$ or $24 \mathrm{~h}$ ) decreased germination, growth survival, frequency of flowering plants and seed setting and no. of seeds in $M_{1}$ generation. With EMS at a low concentration and a short treatment time, the percentage of lethal mutants was reduced and a large non lethal $\mathrm{M}_{2}$ population was obtained.

Van Harten (1998) observed that EMS, a chemical mutagen caused high frequency of gene mutations with low frequency of chromosomal aberrations and hence it was widely used in crop plants. It was reported that genes near the centromere were more prone to mutagenic treatment than those located farther away. Chlorophyll mutants were frequent in EMS treatment but were rare in treatments with physical mutagen and this was attributed to differences in the chemical composition of the chromosomes near the centromere, making them more sensitive to chemical mutagens (Chopra, 2005). Roychowdhury and Tah (2011) treated the seeds of Dianthus carophyllus L. with ethyl methane sulphonate (EMS) and sodium azide (SA) at three different concentrations viz.,
$0.1 \%, 0.4 \%$ and $0.7 \%$. It was reported that increase in the dose of EMS and SA, germination percentage and survivability were decreased at seedling stage, but they were not survived till maturity. Higher lethality over control was shown at $0.7 \%$ EMS. Pollen sterility also increased with increase in mutagenic doses. Singh et al., (2013) reported that, three tuberose (Polianthes tuberosa L.) varieties (Calcutta Double, Prajwal and Shringar) were treated with different concentrations of EMS $0.25 \%$ and $0.5 \%$ for inducing mutations in qualitative and quantitative characters. EMS $(0.25 \%$ and $0.5 \%)$ treated Prajwal variety produced seven, five and eight tepal florets than control (six tepal). In Shringar variety, $0.25 \%$ EMS concentration showed eight tepal florets in $\mathbf{M}_{1}$ generation. Bougainvillea is a flowering plant, highly amenable for mutation induction. the various mutants induced by chemical mutagen at NBRI, Lucknow is presented in table -3 .

Dhivya et al., (2015) reported that crossandra (Crossandra infundibuliformis (L.) NEES) seeds treated with different concentrations of ethyl methane sulphonate $(20,30,40,50$ and $60 \mathrm{mM}$ ) and recorded that the higher internodal length, no. of leaves, length and breadth of leaf, no. of branches and length of branch over control were observed at $30 \mathrm{mM}$ EMS treated seeds. Kayalvizhi et al., (2016b) reported that, tuberose variety Prajwal bulbs treated with chemical mutagens viz., Diethyl Sulphate (DES) @ 15, 20, 25 and $30 \mathrm{mM}$ and Ethyl Methane Sulphonate (EMS) @ 30, 45, 60 and $75 \mathrm{mM}$. The lower doses of the mutagens had recorded higher values for morphological and floral parameters than untreated control. Kayalvizhi et al., (2017b) revealed that the tuberose Prajwal variety bulbs were treated with chemical mutagen DES at different doses. Nine tepal florets were observed in $30 \mathrm{mM}$ of DES and eleven tepal floret was observed in $15 \mathrm{mM}$ of DES. 
Table.1 Gamma ray dosages adopted for different flower crops

\begin{tabular}{|l|l|l|l|}
\hline Ornamentals & Propagation & Mutagen & Dose \\
\hline Amaryllis & Bulb & Gamma rays & 250 rads - 5 Krad \\
\hline Bougainvillea & Stem cuttings & Gamma rays & 250 rad to 1.25 kR \\
\hline Canna & Rhizome & Gamma rays & 2 and 4 Krad \\
\hline Chrysanthemum & Rooted cuttings / suckers & Gamma rays & 1 to 3.5 Krad \\
\hline Gerbera & Rooted plantlet & Gamma rays & 1 and 2 Krad \\
\hline Gladiolus & Bulb & Gamma rays & 250 rads to 5 Krad \\
\hline Hibiscus & Stem cutting & Gamma rays & 1 to 4 Krad \\
\hline Narcissus tazetta & Bulb & Gamma rays & $0.25,0.50$ and 0.75 kR \\
\hline Perennial portulaca & Stem cutting & Gamma rays & $250 \mathrm{rad}$ to 1.25 Krad \\
\hline Polianthes tuberosa & Bulb & Gamma rays & 250 rad to 8 Krad \\
\hline Rose & Stem with budding eyes & Gamma rays & 2 to 6 Krad \\
\hline Tagetes erecta & Rooted cuttings & Gamma rays & 500 rad to 2 Krad \\
\hline Lantana depressa & Stem cutting & Gamma rays & 1 to 4 Krad \\
\hline
\end{tabular}

Table.2 Bougainvillea mutants induced by physical mutagen

\begin{tabular}{|c|c|c|c|c|}
\hline $\begin{array}{l}\text { Original } \\
\text { variety }\end{array}$ & Characters & $\begin{array}{l}\text { Mutant } \\
\text { name }\end{array}$ & Mutagen & Characters \\
\hline $\begin{array}{l}\text { Partha } \\
\text { (Single } \\
\text { bracted) }\end{array}$ & $\begin{array}{lr}\text { Green } & \text { leaves, } \\
\text { bract } & \text { pinkish } \\
\text { purple, } & \text { non- } \\
\text { persistent } & \end{array}$ & Arjuna & Gamma rays & $\begin{array}{l}\text { Variegated leaves, creamish white, } \\
\text { dark and light green, bract pinkish } \\
\text { purple, non persistant }\end{array}$ \\
\hline \multirow[t]{2}{*}{$\begin{array}{l}\text { Los Banos } \\
\text { Beauty } \\
\text { (Double } \\
\text { bracted) }\end{array}$} & $\begin{array}{lr}\text { Green leaves, } \\
\text { persistent bract, } \\
\text { mallow purple } \\
\text { colour }\end{array}$ & $\begin{array}{l}\text { Los Banos } \\
\text { Variegata }\end{array}$ & Gamma rays & $\begin{array}{l}\text { Variegated leaves, margin creamish } \\
\text { white, centre green and light green, } \\
\text { bract persistent }\end{array}$ \\
\hline & & $\begin{array}{l}\text { Los Banos } \\
\text { Variegata } \\
\text { Silver } \\
\text { Margin }\end{array}$ & Gamma rays & $\begin{array}{l}\text { Variegated leaves, margin silver } \\
\text { white, bract persistent, bract colour } \\
\text { mallow purple }\end{array}$ \\
\hline \multirow[t]{2}{*}{$\begin{array}{l}\text { Mahara } \\
\text { (Double } \\
\text { bracted) }\end{array}$} & $\begin{array}{l}\text { Green leaves, } \\
\text { bract persistent, } \\
\text { rhodamine purple } \\
\text { colour bract }\end{array}$ & $\begin{array}{l}\text { Mahara } \\
\text { Variegata }\end{array}$ & Gamma rays & $\begin{array}{l}\text { Variegated leaves, margin creamish } \\
\text { yellow and centre green, persistent } \\
\text { bract, rhodamine purple colour bract }\end{array}$ \\
\hline & & $\begin{array}{l}\text { Mahara } \\
\text { variegate } \\
\text { Abnormal } \\
\text { leaves }\end{array}$ & Gamma rays & $\begin{array}{l}\text { Leaves are abnormal with } \\
\text { asymmetrical lamina, light and dark } \\
\text { green patches, margin undulated, } \\
\text { bract persistent, rhodamine purple } \\
\text { colour bract }\end{array}$ \\
\hline $\begin{array}{l}\text { Roseville's } \\
\text { Delight } \\
\text { (Double } \\
\text { bracted) }\end{array}$ & $\begin{array}{l}\text { Green leaves, } \\
\text { persistent bract, } \\
\text { burnt orange } \\
\text { bract colour }\end{array}$ & Pallavi & Gamma rays & $\begin{array}{l}\text { Variegated leaves, variegation is } \\
\text { prominent in juvenile shoot and } \\
\text { foliage, persistent bract, bract colour } \\
\text { burnt orange }\end{array}$ \\
\hline
\end{tabular}


Table.3 Bougainvillea mutants induced by chemical mutagen

\begin{tabular}{|l|l|l|l|l|}
\hline Original variety & Characters & Mutant name & Mutagen & Characters \\
\hline $\begin{array}{l}\text { Los Banos } \\
\text { Beauty (Double } \\
\text { bracted) }\end{array}$ & $\begin{array}{l}\text { Green leaves, } \\
\text { persistent bract, } \\
\text { mallow purple } \\
\text { colour }\end{array}$ & $\begin{array}{l}\text { Los } \\
\text { Variegata Jayanthi }\end{array}$ & $0.02 \%$ EMS & $\begin{array}{l}\text { Variegated leaves, centre } \\
\text { green and light green and } \\
\text { margin creamish yellow } \\
\text { and white, bract persistent }\end{array}$ \\
\hline $\begin{array}{l}\text { Pixie (Single } \\
\text { bracted) }\end{array}$ & $\begin{array}{l}\text { Green leaves, } \\
\text { bract pinkish } \\
\text { purple, non- } \\
\text { persistent }\end{array}$ & Pixie Variegata & $0.02 \%$ EMS & $\begin{array}{l}\text { Variegated small leaves, } \\
\text { centre green margin } \\
\text { creamish white and light } \\
\text { yellow, bract pinkish } \\
\text { purple and non-persistent }\end{array}$ \\
\hline
\end{tabular}

In tuberose, variety Prajwal bulbs were treated with different dose of chemical mutagens DES and EMS. The study concluded that, the highest number of florets per plant (180.00 nos.) was observed in 25 mM DES whereas minimum (40.00 nos.) was in $75 \mathrm{mM}$ EMS compared to control (140.32) in $\mathrm{M}_{1} \mathrm{~V}_{2}$ generation. The maximum weight of single floret $(1.61 \mathrm{~g})$ was noticed in $20 \mathrm{mM}$ DES while minimum (1.06 g) was in $2.5 \mathrm{kR}$ as compared to the control $(1.15 \mathrm{~g})$. (Kayalvizhi et al., 2017a).

Dhawani et al., 2018 reported that, the gladiolus 'Psittacinus Hybrid' corms were treated with different doses of gamma rays viz. $5.5 \mathrm{kR}, 6.0 \mathrm{kR}, 6.5 \mathrm{kR}, 7.0 \mathrm{kR}, 7.5 \mathrm{kR}$ and $8.0 \mathrm{kR}$ and different concentrations of DES $0.1 \%, 0.2 \%, 0.3 \%, 0.4 \%$ and $0.5 \%$. It was found that DES had more pronounced effect on vegetative characters similarly for flowering characters DES produced larger spikes and with more no. of florets as compared to Gamma rays. Plants were more responsive to treatment of DES as compared to gamma rays.

\section{References}

Ahloowalia, B.S. and M. Maluzynski. 2001. Induced mutations - a new paradigm in plant breeding. Euphytica, 118:167-173.

Auerbach, C. 1967. The Chemical production of mutations. Sci., 158: 1141.
Balakrishnan, S. 1997. Studies on induced mutations in chrysanthemum (Dendranthema grandiflora Tzueleu). Ph.D. Thesis submitted to Tamil Nadu Agricultural University, Coimbatore.

Banerji, B.K. 2008. Induction and analysis of somatic mutation in foliage/bract colour and form in multi-bracted Bougainvillea. In. Abstract of national symposium on recent advances in floriculture. Navsari Agricultural University, India. pp. 138.

Banerji, B.K. and S.K. Datta. 2002. Induction and analysis of gamma rays induced flower head shape mutation in 'Lalima' chrysanthemum (Chrysanthemum morifolium). Indian J. Agric. Sci., 72(1):610.

Bhat, R., N. Upadhaya, A. Chaudhury, A. Raghavan, C. Qiu, F.Wang, H.Wu, J. Mcnally, K. Leiung and B. Till. 2007. Chemical and irradiation induced mutants and tilling. Rice functional genomics, $p$ 148-180.

Broertijes, C. and A.M.V.Harten. 1988. Applied mutation breeding. Elsevier science publishing. Co. New York, p. 246-249.

Chopra, V. L. 2005. Mutagenesis: Investigating the process and processing the outcome for crop improvement. Curr. Sci., 89 (2): 353359.

Datta, S. K. 1990. Induction and analysis of somatic mutations in garden chrysanthemum. Adv. Hort. For., 31: 231 254.

Datta, S.K. 2014. Induced mutagenesis: Basic knowledge for technological success. National Botanical Research Institute 
(NBRI-CSIR), Lucknow, Uttar Pradesh, India. 97-139.

De, L.C. and S.K. Bhattacharjee. 2011. Ornamental crop breeding. Aavishkar Publishers, Distributors, Jaipur, India. pp. 40-41.

Dhawani, P., P. Sudha, M. Sanket and D.Trupti. 2018. Comparative Effect of Physical and Chemical Mutagens in Inducing Variability in Gladiolus Variety 'Psittacinus Hybrid'. International journal of current microbiology applied sciences. 7: 645-652.

Dhivya, M., S. Balakrishanan and S. J. Hephziba. 2015. Radiation induced variability in crossandra (Crossandra infundibuliformis (L.) Nees). International Journal of Agricultural Science and Research. 5(3):267-272.

Dwivedi, A.K. and B.K. Banerji. 2009. Effects of gamma irradiation on Dahlia. cv. Pinki. J. Orn. Hort., (2): 148-151.

El-Kholy, S. A. and E. A. Hassan. 1983. The effect of irradiation and growth substances on seed germination of Strelitizia reginae Banks. Minufiya. J. Agric. Res., 6: 267269.

Fucui, Z., X. Zuoming and H,Yichun. 2011. Study on irradiative mutation breeding of Canna generalis Bailey. Journal of Anhui Agricultural Science. 39:56-58.

Hentrich, W. and M. Glawe. 1982. Breeding carnations using EMS application to the leaf axils of young plants. Archiv-furZuchtungsforschung, 12 : 197-207.

Jompuk, P., S. Wongpiyasatid, S. Lamseejan and K. Chusreeaeom. 2008. Mutation induction using acute and chronic gamma irradiation on some vegetatively propagated crops in Tailand. In: Abstracts of FAO/IAEA International symposium on induced mutations in plants. August 12-15. Vienna, Austria, pp.114.

Jyothi, R and K.P.Singh. 2016. Gamma radiation powerful tool to induce genetic variability in Tuberose. Floriculture Today. 20(10): 30-33.

Kainthura, P. and R. Srivastava. 2015. Induction of Genetic Variability and Isolation of Mutants in Tuberose (Polianthes tuberosa L). Tropical Agricultural Research. 26 (4): $721-732$.
Kayalvizhi K., M. Kannan and M. Ganga. 2016a. Radiation induced variability in tuberose (Polianthes tuberosa L.). Res. Environ. Life Sci. 9(12): 1431-1433.

Kayalvizhi. K, M.Kannan and M.Ganga. 2016b. Mutagenic effects of chemical mutagens on tuberose (Polianthes tuberosa L.) Var. Prajwal. J. Inno. Agri., 3(2):11-13.

Kayalvizhi, K., M. Kannan and M. Ganga. 2017a. Effect of physical and chemical mutagens on morphological characters in $\mathrm{M}_{1} \mathrm{~V}_{2}$ generation of tuberose (Polianthes tuberosa L.). Int.J.Curr.Microbiol.App.Sci 6(4): 2492-2499.

Kayalvizhi, K., M. Kannan and M. Ganga. 2017b. Effect of mutagens on vegetative and floral characters in $\mathrm{M}_{1} \mathrm{~V}_{2}$ generation of tuberose (Polianthes tuberosa L.). Bull. Env. Pharmacol. Life Sci., 6 [1]: 422-429.

Kayalvizhi,K, M.Kannan, M.Ganga and A.Sankari. 2018. Efficiency of physical and chemical mutagens on tuberose (Polianthes tuberosa L.). Multilogic in Sci., 7: Pp 429433.

Konzak, C. F., R. A. Nilan, R. R. Legault and R. E. Heiner. 1961. Modification of induced genetic damage in seeds. In: Proc. Symp. Karisrune. I.A.E.A. and F.A.O, Vienna, pp. 150-169.

Mackey, J. 1967. Physical and chemical mutagenesis in relation to ploidy level. In: Induced mutagenesis and their utilization. Proc. Symp. Berlin. p.185.

Mandal, A. K. A., D. Chakrabarty and S. K. Datta. 2000. In vitro isolation of solid novel flower colour mutants from induced chimeric ray florets of chrysanthemum. Euphytica, 114: 9-12.

Muller, H. J. 1927. Artificial transmission of gene. Sci., 66: 84-87.

Patil, D. S. and H. E. Patil. 2009. Improvement of major ornamental crops through mutation breeding. International Journal of Agricultural Sciences, 5(2): 628-632.

Puripunyavanich, V. and K. Boonsirichai. 2008. Effect of gamma irradiation in 'Jongkolnee' water lily. $31^{\text {st }}$ congress on science and technology of Thailand at Suranaree university of Technology.

Roychowdhury, R. and J. Tah. 2011. Genetic variability study for yield and associated 
quantitative characters in mutant genotypes of Dianthus carophyllus L. Int. J. Biosci., 1(5): 2222-5234.

Schiemann, E. 1912. Mutation bei Aspergillus niger Z. Ind. Abst. u. Vererblehre., 8:1

Schiva, T., B. Ruffoni and R. Vaccarino. 1984. Genetic Variability induced by chemical compounds (EMS) in Gerbera jasmeonii var. Hybrida. Bolus. Annali dell Instuto Sperimentale perla Floriultura, 15(1):29-71.

Singh, I. S. 1976. A dominant mutation for pollen sterility induced by EMS in Petunia. Acad. Sci., 282(9):859-862. Hort. Abstr., 47(1): 634.

Singh, P.K., R. Sadhukhan., K. Roy and H.K. Sarkar. 2013. Effect of EMS on morphoanatomical change in tuberose (Polianthes tuberosa L.). Floriculture and ornamental biotechnology. 7(1): 103-105.

Sparrow, A. H., A. F. Rogers and S. S. Sehwemmer. 1968. Radio sensitivity studies with woody plants. Acute gamma irradiation survival data for 28 species and predictions for 190 species. Radiat., Bot., 8: 149-186.

Sparrow, A. H., L. A. Schairer and R. C. Sparrow. 1963. Relationship between nuclear volumes, chromosome numbers and relative radio sensitivities. Sci., 141: 163-166.

Srivastava, A. and R. Mishra. 2005. Gamma ray induced small flower mutant in Hibiscus rosa sinensis. Mutant Breed. Newsl. Rev., 1: $20-21$

Stadler, L. J. 1928. Mutations in barley induced by X-rays and radiation. Sci., 68: 186-187. Swaminathan, M. S. 1969. Mutation breeding. Proc. XXII. Int. Congr. Genet., 3: 327-247.

Talukdar, C., Madhumita, and L. Paswan. 1997. Gamma ray induced mutation in chrysanthemum. J. Nucl. Agric. Biol., 26(2): 129-131.

Thinh, D. K., N. H. Huyen, P. D. Tuan and N. T. Bich. 2011. Application of induced mutation by using gamma ray treatment in study breeding for orchid(Phalaenopsis) varieties. In: Proc. $9^{\text {th }}$ Nat. Conf. Nucl. Sci. Technol., Vietnam, 43(24): 736-742.

Tiwari, A. K., R. M. Srivastava, Vijai Kumar, L. B. Yadav and S. K. Mishra. 2010. Gammarays induced morphological changes in gladiolus. Prog. Agric., 10: 75-82.

Van Harten, A. M. 1998. Mutation breeding, theory and practical applications. Cambridge, UK Univ. Press.

Wang, H. L., G. M. Li and R. J. Chen. 2006. Fast neutron bombardment (FNB) mutagenesis for forward and reverse genetic plants. In: Floriculture, Ornamental and Plant Biotechnology, Global Science Books Ltd., pp. 629- 639.

Wen, X. and L. Qu. 1996. Crop improvement through mutation technique in Chinese agriculture. Mutat. Breed. Newsl., 42: 3-6.

Zhao, S. W. J. L. L. 2002. Induced mutations for improvement of fruit trees and ornamental plants in China. In: Workshop on mutation breeding, Forum for nuclear co-operation in Asia, Japan.

\section{How to cite this article:}

Kayalvizhi. K., A. Ramesh Kumar, A. Sankari and Anand. M. 2020. Induction of Mutation in Flower Crops - A Review. Int.J.Curr.Microbiol.App.Sci. 9(06): 1320-1329. doi: https://doi.org/10.20546/ijcmas.2020.906.164 